\title{
HUBUNGAN DESAIN KERJA DAN DISIPLIN DENGAN PRODUKTIVITAS PEGAWAI DIREKTORAT JENDERAL PENDIDIKAN NONFORMAL DAN INFORMAL
}

\section{IFRAN KARIM•}

\begin{abstract}
This research aims to determine the relationship: (1) job design with productivity; (2) discipline with productivity; and (3) the relation between job design and discipline with productivity. The research method using survey by correlation approach. This research used as a sample of 80 employees, and 20 employees for testing, and selected based on a simple random technique (simple random sampling). The study was conducted at Directorate General of Non-formal and Informal Education.Technique data collecting was using the instrument in the form of questionnaire. This instrument is calibrated with the test item validity and reliability coefficients. To test the validity of using Pearson Product Moment correlation, while the reliability coefficient is calculated using the formula of Cronbach Alpha.

The results showed that: first, there were positive relationship between job design with productivity; secondly, there is a positive relationship between discipline with productivity; thirdly, there is a positive relationship between job design and discipline together with employees productivity. The implication of this research is an effort in improving the productivity of employees can be done through job design and discipline.
\end{abstract}

Keywords: Job Design, Discipline, Productivity.

\section{PENDAHULUAN}

Pada dasarnya setiap organisasi yang didirikan, baik organisasi pemerintah maupun organisasi swasta mempunyai harapan agar dapat mencapai tingkat produktivitas yang tinggi dalam bidang pekerjaannya. Untuk mewujudkan hal tersebut, diperlukan beberapa faktor pendukung produksi yaitu alam, tenaga kerja, modal, dan keahlian. Keempat faktor tersebut tidak dapat berdiri sendiri, melainkan harus saling mendukung untuk mencapai tujuan secara efektif dan efisien. Dari keempat faktor utama tersebut, faktor sumber daya manusia (SDM) dalam hal ini adalah pegawai, merupakan hal yang terpenting karena SDM merupakan pemakai dan penggerak serta penentu segala aktivitas yang ada di organisasi.

Direktorat Jenderal Pendidikan Non-formal dan Informal (Ditjen PNFI) sebagai salah Unit Utama di Kementerian Pendidikan Nasional mempunyai tanggungjawab dalam pelayanan dan pengembangan pendidikan, khususnya di bidang pendidikan nonformal dan informal. Kualitas output dari lembaga ini akan dipengaruhi oleh mutu pengelolaan atau manajemen organisasi yang dijalankan. Salah satunya adalah faktor pelaksana yakni manusia. Manusia merupakan unsur terpenting dalam proses administrasi dan manajemen bagi semua organisasi.

Setiap organisasi pemerintahan berupaya untuk mendapatkan pegawai yang terlibat dalam kegiatan organisasi dapat memberikan prestasi kerja. Dalam bentuk produktivitas kerja setinggi mungkin untuk mewujudkan tujuan yang telah ditetapkan sebelumnya. Terdapat banyak faktor yang dapat mempengaruhi produktivitas diantaranya (1) sikap mental berupa motivasi kerja, disiplin kerja dan etika kerja; (2) pendidikan; (3) keterampilan; dan (4) manajemen. - Staf Perencanaan dan Penganggaran Ditjen Pendidikan Nonformal dan Informal, Kementerian
Pendidikan dan Kebudayaan RI. 
Pegawai sebagai salah satu komponen organisasi memiliki peranan penting dan ikut menentukan kelancaran dan keberhasilan lembaga dalam melaksanakan tugas dan fungsi yang diembannya. Agar pegawai dapat melaksanakan tugas dengan baik, mereka dituntut untuk memiliki kemampuan dan disiplin yang tinggi.

Dalam prakteknya, masih banyak dijumpai para pegawai yang tidak melaksanakan tugas dengan baik sesuai dengan harapan lembaga tempat ia bekerja. Hal ini menunjukkan bahwa kemampuan, kedisipilinan pegawai dalam melaksanakan tugas masih rendah. Kemampuan dan disipilin pegawai yang masih rendah ditambah dengan belum adanya rancangan pekerjaan yang baik akan menyebabkan merosotnya produktivitas kerja yang pada akhirnya akan berpengaruh terhadap produktivitas organisasi secara keseluruhan.

Masalah produktivitas merupakan masalah nasional, karena menyangkut kualitas sumber daya manusia. Dalam Rencana Pembangunan Jangka Menengah Nasional (RPJMN) 2010 - 2014 ditegaskan bahwa arah kebijakan pembangunan bidang pendidikan diarahkan demi tercapainya pertumbuhan ekonomi yang didukung keselarasan antara ketersediaan tenaga terdidik dengan kemampuan: 1) menciptakan lapangan kerja atau kewirausahaan dan 2) menjawab tantangan kebutuhan tenaga kerja. Hal ini menunjukkan bahwa pembangunan sumber daya manusia menjadi pusat perhatian di masa datang, karena kunci keberhasilan pembangunan sangat tergantung pada manusia-manusianya.

Usaha untuk meningkatkan produktivitas kerja telah banyak dilakukan oleh pemerintah. Pemerintah pernah merintis program peningkatan produktivitas tenaga kerja dengan mendirikan Pusat Produktivitas Tenaga Kerja dan Dewan Produktivitas Nasional pada awal tahun 1970-an serta melakukan kampanye peningkatan produktivitas di segala bidang. Dalam hal ini produktivitas turut menentukan pembentukan indeks pertumbuhan nasional.

Peningkatan produktivitas secara menyeluruh akan menunjukkan potensi pengadaan barang dan jasa dalam jumlah yang lebih besar bagi para pekerja. Ini berarti dapat menjamin peningkatan pendapatan pekerja, yang berarti pula dapat meningkatkan daya beli masyarakat akan barang dan jasa.

Untuk mencapai produktivitas yang tinggi pimpinan organisasi pemerintahan harus memperhatikan semangat kerja. Semangat kerja merupakan sikap mental yang mampu memberikan dorongan bagi seseorang untuk dapat bekerja lebih giat, cepat, dan baik. Semangat kerja pegawai yang tinggi akan berpengaruh terhadap efisiensi kerja dan efektivitas kerja.

Produktivitas kerja pegawai negeri yang bekerja belum banyak dikaji secara ilmiah. Namun demikian, pengertian produktivitas tenaga kerja telah banyak diungkapkan oleh para ahli, terutama produktivitas tenaga kerja di lingkungan perusahaan atau industri.

Salah satu faktor lain yang menentukan produktivitas adalah disiplin. Hilangnya disiplin akan berpengaruh terhadap efisiensi kerja dan efektivitas tugas pekerjaan.

Dengan adanya kedisiplinan diharapkan pekerjaan akan dilakukan seefektif mungkin. Hal tersebut sejalan dengan pandangan Muchdarsyah yang mengatakan bahwa disiplin mendorong produktivitas atau disiplin merupakan sarana penting untuk mencapai produktivitas.

Sebagai gambaran apabila suatu organisasi hanya memperhatikan tentang pendidikan, keahlian dan teknologi tanpa memikirkan semangat dan disiplin kerja pegawai, maka pendidikan, keahlian dan teknologi yang tinggi sekalipun tidak akan 
menghasilkan produk yang maksimal bila yang bersangkutan tidak dapat memanfaatkannya secara teratur dan mempunyai kesungguhan disiplin kerja yang tinggi.

Desain Pekerjaan adalah fungsi penetapan kegiatan-kegiatan kerja seorang individu atau kelompok karyawan secara organisasional. Dalam hal ini desain pekerjaan tujuannya untuk mengatur penugasan-penugasan kerja yang memenuhi kebutuhan organisasi, teknologi, dan keperilakuan. Desain pekerjaan yang diberikan kurang jelas akan mengakibatkan karyawan kurang mengetahui tugas dan tanggung jawabnya yang akan mempengaruhi gairah karyawan dalam bekerja, hal ini mengakibatkan pekerjaan tidak tercapai dengan baik.

Desain pekerjaan mutlak diperlukan oleh setiap organisasi karena dalam desain pekerjaan, yang dilakukan adalah merakit sejumlah tugas menjadi sebuah pekerjaan atau sekelompok pekerjaan agar perkerjaan yang dilakukan menjadi terarah jelas dan pekerjaan dapat dilakukan secara efisien dan efektif. Desain pekerjaan senantiasa mempengaruhi seluruh kondisi dasar perilaku individu-individu dalam organisasi dengan menciptakan motivasi pada setiap pegawainya yaitu dengan cara membuat desain pekerjaan yang jelas signifikansi tugasnya, keberagaman tugas yang dikerjakan dan apakah pekerjaan yang dibuat dapat mengembangkan kemampuan pegawainya. Hal ini sesuai dengan pandangan Debra L Nelson \& James Campbell Quick yang mengatakan: "Good job design helps avoid these problems, improves, productivity, and enhances employee weil-being". Dijelaskan bahwa desain pekerjaan yang baik membantu menghindari masalah, meningkatkan produktivitas, dan meningkatkan kesejahteraan karyawan.

Selama ini usaha peningkatan produktivitas lebih banyak dilakukan melalui peningkatan pengetahuan dan keterampilan, padahal untuk meningkatkan pengetahuan dan keterampilan tersebut perlu dilakukan latihan atau training yang memerlukan adanya pengorbanan dana (biaya) dan waktu yang tidak sedikit. Oleh karena itu peningkatan desain kerja dan disiplin kerja merupakan faktor yang perlu untuk diperhatikan dalam usaha mencapai produktivitas yang tinggi.

Dari alasan dan kondisi tersebut di atas maka peneliti tertarik untuk mengangkat suatu penelitian dengan judul: "Hubungan Desain Kerja dan Disiplin dengan Produktivitas Pegawai Direktorat Jenderal Pendidikan Nonformal dan Informal"

Produktivitas. Menurut Robbins \& Coulter, produktivitas didefinisikan sebagai "the overall output of goods produced divided by the inputs needed to generate that output". Produktivitas adalah keseluruhan output yang dihasilkan dibagi dengan jumlah input yang diperlukan untuk menghasilkan output. Kemudian Newstrom mengemukakan

pengertian produktivitas "productivity, at its simplest, is a ratio that compares units of output with units of input, often againts a predetermined standard". Produktivitas mengandung pengertian secara sederhana adalah perbandingan antara jumlah unit keluaran yang dicapai dengan jumlah unit masukan, sesuai standar yang telah ditetapkan.

Produktivitas tenaga kerja adalah salah satu ukuran perusahaan dalam mencapai tujuannya. Sumber daya manusia merupakan elemen yang paling strategik dalam organisasi, harus diakui dan diterima oleh manajemen. Peningkatan produktivitas kerja hanya mungkin dilakukan oleh manusia.

Produktivitas kerja merupakan tingkat keunggulan yang diharapkan dan pengendalian atas tingkat keunggulan untuk memenuhi keinginan konsumen. 
Produktivitas dimulai dari kebutuhan pelanggan dan berakhir pada persepsi pelanggan. Hal ini dapat diimplementasikan interaksi antara pegawai (pekerja) dan pelanggan yang mencakup (a) ketepatan waktu, berkaitan dengan kecepatan memberikan tanggapan terhadap keperluan-keperluan pelanggan; (b) penampilan karyawan, berkaitan dengan kebersihan dan kecocokan dalam berpakaian; (c) kesopanan dan tanggapan terhadap keluhan, berkaitan dengan bantuan yang diberikan dalam menyelesaikan masalah-masalah yang diajukan pelanggan. Produktivitas yang baik dilihat dari persepsi pelanggan bukan dari persepsi organisasi. Persepsi pelanggan terhadap produktivitas jasa merupakan penilaian total atas kebutuhan suatu produk yang dapat berupa barang ataupun jasa.

Produktivitas bukan semata-mata ditujukan untuk mendapatkan hasil kerja sebanyak-banyaknya, melainkan kualitas unjuk kerja juga penting diperhatikan. Hal itu sejalan dengan pandangan Laeham \& Wexley, 1982 (dalam Sedarmayanti, 2009) yang mengatakan bahwa:

...performance appraisals are crucial to the effectivity management of an organization's human resources, and the proper management of human resources is a critical variable effecting an organization's productivity. (....Produktivitas individu dapat dinilai dari apa yang dilakukan individu tersebut dalam dalam kerjanya atau unjuk kerjanya).

Sementara pendapat lain tentang produktivitas dikemukakan oleh Courbois \& Temple (1975) sebagai berikut: Productivity is a measure of output from a production process, per unit of input.. (Produktivitas adalah ukuran output dari suatu proses produksi, per unit input). Senada dengan itu, Gomez-Mejia at el (2005) mengemukakan bahwa produktivitas adalah ukuran dari seberapa baik suatu organisasi memanfaatkan semua sumber daya, seperti modal, tenaga kerja, bahan, atau energi, untuk menghasilkan output.

Beberapa definisi tentang produktivitas di atas tampak menyiratkan produktivitas secara total atau secara keseluruhan, artinya keluaran yang dihasilkan diperoleh dari keseluruhan masukan yang ada dalam organisasi. Masukan tersebut lazim disebut sebagai faktor produksi. Keluaran yang dihasilkan dicapai dari masukan yang melakukan proses kegiatan, yang bentuknya dapat berupa barang atau jasa. Sedangkan, masukan atau faktor produksi dapat berupa tenaga kerja, modal, bahanbahan, teknologi, dan manajemen. Salah satu masukan, seperti tenaga kerja, dapat menghasilkan keluaran yang dikenal dengan produktivitas parsial.

Desain Kerja. Desain pekerjaan (job design) adalah suatu alat untuk memotivasi dan memberi tantangan kepada pegawai. Oleh karena itu organisasi perlu memiliki suatu sistem kerja yang dapat menunjang tujuan organisasi secara efektif dan efisien yang dapat merangsang pegawai untuk bekerja secara produktif, mengurangi timbulnya rasa bosan dan dapat meningkatkan kepuasan kerja.

Desain pekerjaan merupakan salah satu faktor pendorong keberhasilan produktivitas organisasi. Dari dimensi organisasi, cara pengelompokan tugas dan tanggung jawab dapat mempengaruhi produktivitas dan biaya.

Noel Harvey dalam bukunya "the Challenge of Supervisory Management" mendefinisikan desain kerja sebagai berikut:

Job design is thus compromise between the organisation's needs for productivity, efficiency, and quality, and the needs of the individual for interesting and challenging work. (Desain pekerjaan merupakan kompromomi antara kebutuhan 
organisasi untuk meningkatkan produktivitas, efisiensi, dan kualitas, serta kebutuhan individu untuk pekerjaan menarik dan menantang).

Sedangkan Moorhead menyatakan bahwa: "Design work is how organizations define and develop jobs. (Desain pekerjaan adalah bagaimana organisasi mendefinisikan dan menyusun pekerjaan-pekerjaan). Robert L Mathis dan John $H$ Jackson mengemukakan bahwa "Job design - refers to organizing tasks, duties, responsibilities, and other elements into a productive unit of work". Artinya, desain pekerjaan mengacu pada pengorganisasian tugas-tugas, tanggung jawab, dan elemen lainnya agar pekerjaan menjadi produktif.

Robbins \& Coulter menyebutkan desain pekerjaan sebagai "cara penugasan dan penggabungan agar pekerjaan selesai. Pekerjaan yang dilakukan orang dalam organisasi tidak berkembang secara kebetulan. Manager harus sengaja merancang pekerjaan dan memikirkan sesuai dengan keterampilan, kemampuan, dan keinginan karyawan.

Pendapat lain dikemukan Fred Luthans dalam bukunya Organizational Behavior yang mendefinisikan desain kerja sebagai berikut:

Job design may be defined as the methods that management uses to develop the content of a job, including all relevant task, as well as the processes by which jobs are constructed and revised. (desain pekerjaan dapat didefinisikan sebagai metode yang digunakan untuk mengembangkan manajemen isi pekerjaan, termasuk semua tugas yang relevan, serta proses pekerjaan yang dibangun dan direvisi).

Selanjutnya Kreitner dan Kinicki dalam bukunya "organizational behavior" menyatakan bahwa desain pekerjaan bertujuan untuk meningkatkan mutu pekerjaan dan produktivitas karyawan.

Job design also referred to as job redesign refers to any set of activities that involve the alteration of specific jobs or interdependent system of jobs, with the intent of improving the quality of employee job experience and their on the job productivity.

Desain pekerjaan adalah proses dimana manajer menentukan tugas-tugas individual dan wewenangnya. Ini berarti manajemen telah memutuskan bahwa lebih bermanfaat untuk mempertimbangkan kembali apa yang diharapkan karyawan dalam melakukan pekerjaan.

Inti dalam menyusun desain kerja adalah bagaimana cara membuat semua pekerjaan yang ada disusun secara sistematis. Desain kerja membantu dalam mejelaskan

pekerjaan apa yang harus dikerjakan, bagaimana menyelesaikan pekerjaan tersebut, berapa banyak pekerjaan yang harus dilakukan dan bagaimana ketentuan yang harus dijalankan sehingga pekerjaan dapat diselesaikan.

Dari beberapa konsep dan teori di atas, maka dapat disintesakan bahwa desain kerja adalah penetapan pekerjaan seseorang atau sekelompok karyawan secara organisasional dengan tujuan untuk mengatur penugasan kerja agar dapat memenuhi kebutuhan organisasi. Dilakukan dengan mengidentifikasikan seluruh pekerjaan, tugastugas, dan tanggung jawab yang ada dalam organisasi, mengalokasikan kepada pegawai berdasarkan kriteria (kompetensi) tertentu dan mengorganisasikannya dalam suatu susunan yang dapat menjadikan keseluruhan alur pekerjaan menjadi pendukung dalam pencapaian kinerja organisasi secara optimum. 
Disiplin. Disiplin adalah suatu kebiasaan untuk melakukan suatu tindakan tertentu. Disiplin adalah latihan yang menghasilkan pola perilaku yang diinginkan, kebiasaan yang diharapkan, dan sikap yang membawa pada keberhasilan dalam kehidupan. Oleh sebab itu, disiplin adalah suatu yang kita perlukan untuk membawa kita sampai kepada tujuan yang diinginkan. Newstrom (2007), memberikan definisi disiplin sebagai "disciplin is management action to enforce organizational standard". Disiplin adalah tindakan manajemen untuk menegakkan standar organisasi.

Disiplin itu sendiri diartikan sebagai kesediaan seseorang yang timbul dengan kesadaran sendiri untuk mengikuti peraturan-peratuan yang berlaku dalam organisasi. Gomez-Mejia, Balkin, dan Cardy mengemukakan bahwa disiplin merupakan salah satu alat yang digunakan manajemen untuk mengubah perilaku karyawan ketika tidak sesuai harapan atau ketika tidak patut. Contoh perilaku yang tidak memenuhi harapan adalah ketika seorang karyawan datang terlambat untuk bekerja tanpa alasan yang wajar.

Dari beberapa Konsep dan teori di atas, maka dapat disintesakan bahwa disiplin adalah ketaatan yang disadari oleh kesadaran dan keinsafan pegawai untuk mematuhi aturan yang berlaku dalam organisasi, yang meliputi kepatuhan dan ketaatan terhadap peraturan, kepatuhan terhadap jam kerja, kepatuhan dalam menentukan perintah dinas, tanggungjawab terhadap tugas, dan kesadaran dalam melaksanakan tugas.

\section{METODE}

Metode penelitian yang digunakan pada penelitian ini adalah metode survey, dengan pendekatan korelasional. Penelitian ini dilaksanakan di Direktorat Jenderal Pendidikan Nonformal dan Informal Kementerian Pendidikan Nasional RI pada bulan April - Mei 2011. Populasi dalam penelitian ini adalah semua Pegawai yang bertugas Direktorat Jenderal Pendidikan Nonformal dan Informal Kementerian Pendidikan Nasional RI. Populasi terjangkau pada penelitian ini adalah Pegawai Direktorat Jenderal Pendidikan Nonformal dan Informal Kementerian Pendidikan Nasional RI dengan sample frame sebanyak 372 orang.

\section{HASIL PENELITIAN DAN PEMBAHASAN}

\section{Hubungan antara Desain Kerja dengan Produktivitas}

Hasil analisis korelasi antara desain kerja dengan produktivitas dapat diperoleh koefisien korelasi sebesar 0,637 $\left(\mathrm{r}_{\mathrm{y} 1}=0,637\right)$. Nilai ini memberikan pengertian bahwa keterkaitan antara Desain Kerja dengan Produktivitas adalah signifikan atau positif. Artinya, semakin bagus Desain Kerja, akan semakin tinggi pula Produktivitas tersebut. Sedangkan koefisien determinasi diperoleh dari kuadrat koefisien korelasi antara Desain Kerja $\left(X_{1}\right)$ dan Produktivitas $(Y)$ yaitu sebesar $r_{y 1}{ }^{2}=(0,637)^{2}=0,40619$. Ini menunjukkan bahwa 40,619\% Produktivitas dapat ditentukan oleh Desain Kerja.

Selanjutnya untuk mengetahui keeratan hubungan antara Desain Kerja $\left(\mathrm{x}_{1}\right)$ dengan Produktivitas $(Y)$ secara parsial, perlu dilakukan pengontrolan pengaruh variabel Disiplin $\left(\mathrm{X}_{2}\right)$ terhadap Produktivitas $(\mathrm{Y})$ dengan koefisien korelasi parsial = 0,336. Setelah dikontrol variabel Disiplin $\left(X_{2}\right)$, menunjukkan bahwa hubungan antara Desain Kerja $\left(\mathrm{X}_{1}\right)$ dengan Produktivitas $(\mathrm{Y})$ adalah menunjukkan hubungan yang tetap positif dan signifikan pada taraf $a=0,01$. Hal ini sejalan oleh teori Noel Harvey sebagai 
berikut: "Job design is thus a compromise between the organisation's needs for productivity, efficiency, and quality, and the needs of the individual for interesting and challenging work". Noel menjelaskan bahwa desain pekerjaan merupakan kompromi antara kebutuhan organisasi untuk meningkatkan produktivitas, efisiensi, dan kualitas, serta kebutuhan individu untuk pekerjaan menarik dan menantang.

Selanjutnya Robert L Mathis dan John H Jackson mengemukakan bahwa "Job design - refers to organizing tasks, duties, responsibilities, and other elements into a productive unit of work". Artinya, desain pekerjaan mengacu pada pengorganisasian tugas-tugas, tanggung jawab, dan elemen lainnya agar pekerjaan menjadi produktif.

\section{Hubungan antara Disiplin dengan Produktivitas}

Hasil analisis korelasi antara disiplin dengan produktivitas dapat diperoleh koefisien korelasi sebesar 0,628 $\left(\mathrm{r}_{\mathrm{y} .2}=0,628\right)$. Nilai ini memberikan pengertian bahwa keterkaitan antara Disiplin dengan Produktivitas adalah signifikan atau positif. Artinya, semakin tinggi tingkat Disiplin, akan semakin tinggi pula Produktivitas.

Sedangkan koefisien determinasi diperoleh dari kuadrat koefisien korelasi antara Disiplin $\left(X_{2}\right)$ dan Produktivitas $(Y)$ yaitu sebesar $r_{y 2}{ }^{2}=(0,628)^{2}=0,39401$. Ini menunjukkan bahwa 39,401\% Produktivitas dapat ditentukan oleh Disiplin. Selanjutnya untuk mengetahui keeratan hubungan antara Disiplin $\left(\mathrm{X}_{2}\right)$ dengan Produktivitas $(\mathrm{Y})$ secara parsial, perlu dilakukan pengontrolan pengaruh variabel Desain Kerja $\left(X_{1}\right)$ terhadap Produktivitas $(Y)$ dengan koefisien korelasi parsial $=0,308$, setelah dikontrol variabel Desain Kerja $\left(\mathrm{X}_{1}\right)$, menunjukkan bahwa hubungan antara Disiplin $\left(\mathrm{X}_{2}\right)$ dengan Produktivitas $(\mathrm{Y})$ adalah menunjukkan hubungan yang tetap positif dan signifikan pada taraf $\alpha=0,01$.

Temuan ini mendukung pendapat para ahli yang menyatakan bahwa Disiplin berhubungan positif dengan Produktivitas. Salah satunya yang dikemukan oleh Alfred Sloan dari General Motors Management bahwa dalam sebuah perusahaan termasuk General Motors (GM) membutuhkan dua hal yakni pruduktivitas dan disiplin, yang keduanya

akan membawa kesuksesan bagi sebuah perusahaan. "...And a company is an economic organization and needs productivity and discipline. At GM we get both and to get both we need the union relations we have."

Selanjutnya Edwards menyatakan "The contemporary approach to increasing discipline and productivity is a far more encompassing strategy that seeks to find (or make) the good worker." Dijelaskan bahwa salah satu strategi untuk menciptakan pekerja yang handal adalah melalui peningkatan disiplin dan produktivitas.

Besarnya sumbangan atau kontribusi variabel Disiplin terhadap Produktivitas dapat diketahui dengan jalan mengkuadratkan perolehan nilai koefisien korelasi sederhananya, yang disebut dengan koefisien determinasi. Secara statistik memberikan pengertian bahwa, kurang lebih dengan nilai koefisien determinasi, variasi Produktivitas ditentukan/dijelaskan oleh Disiplin dengan pola hubungan fungsionalnya seperti yang ditunjukkan oleh persamaan regresi.

\section{Hubungan antara variabel Desain Kerja dan Disiplin dengan Produktivitas}

Hasil analisis korelasi ganda antara desain kerja dan disiplin dengan produktivitas dapat diperoleh koefisien korelasi ganda sebesar 0,731 $\left(\mathrm{r}_{\mathrm{y} \cdot 12}=0,731\right)$. Nilai ini menunjukkan bahwa keterkaitan antara Desain Kerja dan Disiplin secara bersama- 
sama dengan Produktivitas adalah signifikan atau positif. Artinya, semakin bagus Desain Kerja dan semakin tinggi tingkat Disiplin pegawai, akan diikuti dengan semakin tingginya Produktivitas pegawai tersebut. Dari koefisien korelasi ganda, diperoleh koefisien determinasi hubungan antara Desain Kerja $\left(X_{1}\right)$ dan Disiplin $\left(X_{2}\right)$ secara bersama-sama dengan Produktivitas $(Y)$ sebesar $(0,731)^{2}=0,535$. Hal ini menunjukkan $53,5 \%$ variabel Produktivitas $(Y)$ dapat dijelaskan oleh variabel Desain Kerja $\left(X_{1}\right)$ dan Disiplin $\left(X_{2}\right)$ yang secara bersama-sama memberi sumbangan efektif sebesar $53,5 \%$. Hasil analisis korelasi ganda antara Desain Kerja dan Disiplin dengan Produktivitas diperoleh nilai koefisien korelasi ganda. Nilai ini menunjukkan bahwa keterkaitan antara Desain Kerja dan Disiplin secara bersama-sama dengan Produktivitas adalah signifikan atau positif. Artinya, semakin bagus Desain Kerja dan semakin tinggi tingkat Disiplin pegawai, akan diikuti dengan semakin tingginya Produktivitas pegawai tersebut.

Hal ini sesuai dengan teori yang dikemukan oleh ahli sebagaimana dikemukakan pada Bab II. Seperti yang di jelaskan dalam empat belas prinsip Fayol, yaitu:

(1) division of work, (2) authority (3) discipline, (4) unity of command, (5) unity of direction, (6) subordination of individual interest to the general interest, (7) remuneration, (8) centralization, (9) scalar chain, (10) order, (11) equity, (12) stability and tenure of personnel, (13) initiative, (14) esprit de corps.

Dari ke empat belas prinsip Fayol tersebut di atas, nampak bahwa produktivitas dapat dihasilkan paling tidak oleh tiga prinsip, yakni: (1) pembagian kerja yang di dalamnya termasuk desain kerja dan spesialisasi pekerjaan untuk meningkatkan efisiensi kerja sehingga mendorong kecepatan dan ketepatan kerja yang pada akhirnya meningkatkan produktivitas, (2) kewenangan dan tanggung jawab, dan (3) disiplin, dalam hal ini mengacu pada ketaatan, melakukan yang tepat dalam hubungannya dengan orang lain, menghormati otoritas, dan sangat penting untuk kelancaran semua fungsi organisasi.

Ketiga prinsip ini apabila dapat dilaksanakan secara baik dan tepat akan menentukan tingkat produktivitas yang hasilkan.

Besarnya sumbangan atau kontribusi variabel Desain Kerja dan Disiplin secara bersama-sama terhadap Produktivitas dapat diketahui melalui nilai koefisien determinasi. Hasil analisis tersebut menunjukkan bahwa, kurang lebih dengan nilai koefisien determinasi, varians Produktivitas ditentukan/dijelaskan oleh Desain Kerja dan Disiplin

secara bersama-sama dengan pola hubungan fungsionalnya seperti yang ditunjukkan oleh persamaan regresi.

\section{PENUTUP}

Kesimpulan. Pertama, terdapat hubungan positif antara Desain Kerja dengan Produktivitas, yang ditentukan oleh derajat kekuatan hubungan dalam bentuk koefisien korelasi dan koefisien determinasi. Kedua, terdapat hubungan positif antara Disiplin dengan Produktivitas, yang ditentukan oleh derajat kekuatan hubungan dalam bentuk koefisien korelasi dan koefisien determinasi. Ketiga, terdapat hubungan positif antara Desain Kerja dan Disiplin secara bersama-sama dengan Produktivitas, yang ditentukan oleh derajat kekuatan hubungan dalam bentuk koefisien korelasi ganda dan koefisien determinasi jamak. 
Implikasi. Hasil penelitian yang telah diperoleh ini mempunyai implikasi penting untuk meningkatkan kepuasan mahasiswa khususnya pada Mahasiswa Fakultas Ilmu Sosial UNJ. 1) Upaya meningkatkan Desain Kerja dalam rangka meningkatkan Produktivitas pegawai, Hasil analisis dan kesimpulan penelitian menyatakan terdapat hubungan positif dan signifikan antara Desain Kerja dengan Produktivitas pegawai. 2) Upaya meningkatkan Disiplin pegawai dalam rangka meningkatkan Produktivitasnya, Hasil analisis dan kesimpulan penelitian menyatakan terdapat hubungan positif dan signifikan antara Disiplin dengan Produktivitas pegawai.

Saran. (1) Bagi pemerintah, pemerintah perlu menetapkan kebijakan dalam rangka peningkatan Produktivitas pegawai dan pemerintah perlu menetapkan kebijakan tentang pemberian reward/pengharagaan kepada pegawai atas prestasi yang telah dicapai serta memfasilitasi pegawai dalam mengembangkan prestasi kerjanya. (2) Bagi Pimpinan di Direktorat Jenderal Pendidikan Non-formal dan Informal, perlu adanya kesadaran dalam diri Pimpinan di Direktorat Jenderal Pendidikan Non-formal dan Informal akan pentingnya peningkatan Produktivitas pegawai yang dalam hal ini dapat ditingkatkan melalui peningkatan Desain Kerja dan Disiplin pegawai. (3) Bagi pegawai, para pegawai disarankan untuk senantiasa berupaya meningkatkan produktivitas kerja baik secara kualitas maupun kuantitas dengan berpedoman pada tugas dan fungsi (TUSI) sebagai Pegawai di Direktorat Jenderal Pendidikan Non-formal dan Informal dan standar kinerja yang telah ditetapkan. (4) Bagi Para Peneliti, berdasarkan pada keterbatasan penelitian ini, bagi para peneliti agar melibatkan lebih banyak variabel yang diduga memiliki hubungan positif dengan Produktivitas pegawai, serta dengan mengambil sampel yang lebih besar.

\section{DAFTAR RUJUKAN}

Debra L Nelson \& James Campbell Quick.Organizational Behavior: Science, The Real World, and You. Seventh Edition.USA: South-Western Cengage Learning, 2011.

Gaspersz, Vincent. Total Quality Management. Jakarta: Gramedia. 2003

Gomez-Mejia, Balkin, Cardy. Management: People, Performance, Change. New York: McGraw-Hill, 2005.

Handoko, T. Hani. Manajemen Personalia dan Sumber Daya Manusia. Yogyakarta: BPFE.2008

Luthans, Fred. Organizational Behavior. Mc Graw-Hill Book Elevent Edition. Singapore, 2008

Kreitner, Robert and Angelo Kinicki, Organizational Behavior, NewYork: McGraw Hill, 2007

Moorhead, Gregory: Griffin, W Ricky. Organizational Behaviour - Managing People and Organization. India: ATTBS Publisher \& Distributor. 2006

Newstrom, John W: Organizational Behavior: Human Behavior at Work. New York: McGraw-Hill, 2007.

Noel Harvey: The Challenge of Supervisory Management. Ireland: Oak Tree Press, 1997. Papalia, D. E.; Wendkos-Olds, S.; Duskin-Feldman, R. A Child's World: Infancy Through Adolescence (10th ed.), Discipline. New York: McGraw-Hill, 2006. dalam http://en.wikipedia.org/wiki/discipline 
Robbins, S.P \& Coulter, Mary: Management. New Jersey: Pearson Prentice Hall, 2007.

Robert L Mathis \& John H Jackson: Human Resouce Management. Twelfth Edition. USA: Thomson South-Western, 2008.

Sedarmayanti. Sumber Daya Manusia dan Produktivitas Kerja. Bandung: Mandar Maju. 2001

Siagian, P Sondang. Kiat Meningkatkan Produktivitas Kerja. Jakarta: PT. Rineka Cipta,2009 Sinungan, Muchdarsyah. Produktivitas Apa dan Bagaimana.Edisi Cetakan ketujuh.Jakarta: PT. Bumi Aksara, 2008.

Peraturan Presiden Nomor 5 Tahun 2010 Tentang Rencana Pembangunan Jangka Menengah Nasional (RPJMN) 2010-2014 